\title{
STUDI TENTANG MADUMONGSO PADA USAHA KECIL MENENGAH (UKM) KELAPA SARI KABUPATEN BLITAR
}

\author{
Sukamto $^{1^{*}}$, Sudiyono ${ }^{1}$, Wahyu Wulandari ${ }^{2}$ \\ ${ }^{1}$ Jurusan Teknologi Hasil Pertanian, Fakultas Pertanian, Universitas Widyagama Malang, Malang, Indonesia \\ ${ }^{2} J u r u s a n$ Manajeman, Fakultas Ekonomi, Universitas Widyagama Malang, Malang, Indonesia \\ *Penulis Korespodensi: kamto@widyagama.ac.id
}

\begin{abstract}
Abstrak
Madumongso merupakan salah satu produk pangan tradisonal masyarakat Jawa yang mana saat ini mulai terancam dengan hadirnya produk-produk pangan impor.Salah satu sentra produksi madumongso yang sekarang masih bertahan adalah usaha kecil menengah Kelapa Sari di kabupaten Blitar. Tujuan kegiatan adalah untuk mempelajari teknologi proses produksi dan manajemen sebagai upaya memperbaiki citra produk madumongso agar mampu meningkatkan daya saing dan segementasi pasar baik dalam maupun luar negeri. Metode pelaksanaan kegiatan pada Mei sampai Agustus 2017 dengan cara survey dan wawancara langsung pada usaha kecil menengah Madumongso Kelapa Sari di Kabupaten Blitar dan memberi solusi alternatif . Hasil kegiatan menunjukan bahwa proses produksi menggunakan jedi kusus yang dilengkapi mesin pengaduk semi otomatis sehingga control kualitas lebih terjamin. Bidang manajemen dan pemasaran produk mengalami peningkatan 10-20 persen pada tahun 2017 dibandingkan tahun 2016. Pasar luar negeri terbangun karena jasa Tenaga Kerja Indonesia yang bekerja di Luar Negeri. Kesimpulan dari hasil kegiatan adalah bahwa produk madumongso sangat potensi untuk dikembangkan menjadi produk andalan usaha kecil menengah baik untuk pasar domestic maupun mancanegara. Berbagai sentuhan teknologi, manajemen produksi dan pemasaran perlu dikembangkan secara berkelanjutan.
\end{abstract}

Kata kunci : Madumongso, UKM, Manajemen, Produksi

\begin{abstract}
Madumongso is one of the traditional Javanese food products which is currently threatened by the presence of imported food products. One of the madumongso production centers that still survive is the small and medium business (UKM) Kelapa Sari in Blitar district. The purpose of the activity is to study the production process and management technology as an effort to improve the image of madumongso product in order to increase the competitiveness and market segementation both domestic and abroad. Methods of implementation of activities in May to August 2017 by way of direct survey and interview on small business Madumongso Kelapa Sari in Blitar regency and providing alternative solutions. The results show that the production process using a special jedi equipped with semi-automatic stirring machine so that quality control is more secure. The field of product management and marketing has increased 10-20 percent by 2017 compared to 2016. Foreign markets are built on the services of Indonesian Migrant Workers working abroad. The conclusion of the activity result is that madumongso product is very potential to be developed into a mainstay product of small and medium enterprises both for domestic and foreign market. A variety of touch technologies, production management and marketing needs to be developed in a sustainable manner.
\end{abstract}

Key words: Madumongso, UKM, Management, Production

\section{PENDAHULUAN}

Madumongso merupakan salah satu jenis makanan tradisional yang terbuat dari ketan hitam yang difermentasi, setelah itu dimasak ditambah dengan santan dan gula dalam wajan atau jedi sampai lekat sehingga menyerupai dodol (Anindya, 2015, http://,wikipedia.org /wiki/madu_mongso). Ketan hitam termasuk salah satu komoditi yang sangat potensial sebagai sumber karbohidrat, antioksidan, senyawa bioaktif, dan serat yang penting bagi kesehatan (Nailufar, Basito dan Anam, 2012). Makanan ini memilki cita rasa yang khas dan gurih berwarna coklat kehitaman dan memiliki tekstur yang lunak setelah dimasak. Ciri khas dari madumongso adalah menggunakan bahan dasar utama dari tape ketan hitam. Produk madumongso dapat dibuat dari bahan ketan hitam yang dicampur dengan ketan putih dengan perbandingan $3: 1$ selanjutnya dikukus dan difermentasi menggunakan ragi tape (Sukamto, 
Sudiyono, Wulandari, dan Figih, 2016). Dijelasknan pula bahwa proses produksi produk madumongso tidak menggunakan bahan kimia sintetik seperti penyedap, pemanis buatan, pengawet dan bahan tambahan makanan lainnya.

Madumongso yang diproduksi oleh UKM Kelapa Sariberpotensi untuk dikembangkan sebagai produk ekspor,karena produknya unik dan telah diminati oleh konsumen baik dalam negeri maupun manca negara. Disamping itu produk tersebut merupakan warisan budaya Jawa dan disajikan pada saat punya hajat besar (pernikahan, hari-hari besar dan ritual khusus). Usaha madumongso pada UKM Kelapa Sari tersebut merupakan usaha turun temurun berdiri sejak tahun 1985. Disisi lain madumongso sekarang sudah mulai asing terdengar, terutama di kalangan anak muda, karena keberadaanya sudah mulai jarang ditemui, kalaupun ada biasanya di wilayah pedesaan dan dijumpai pada saat ada hajatan atau suguhan pada hari raya idul fitri. Menurut Sukamto et al. (2016) kriteria madumongso yang baik diukur melalui dua aspek yaitu aspek subyektif dan obyektif, aspek subyektif yang terdiri dari warna madumongso hitam kecoklatan, tekstur yang lunak dan kalis, aroma khas, rasa rasa manis, gurih, dan sedikit asam khas tape, sedangkan aspek obyektif mirip dengan syarat mutu dodol dimana syarat tersebut sesuai dengan standar yang telah ditetapkan departemen perindutrian yaitu SNI-2986-1992. Permasalahan yang dihadapi oleh UKM madumongso Kelapa Sari adalah (1). Perhatian dan minat generasi muda terhadap makanan madumongso cenderung menurun. (2). Teknologi produksi, manajemen dan pemasaran sebagian besar masih menggunakan cara-cara konvensional dan (3). Perlindungan hukum, labelling, merek dan jaminan halal masih sangat lemah. Permasalahan tersebut dapat mengakibatkan posisi tawar UKM menjadi semakin turun.

Tujuan penulisan atau pelaksanaan kegiatan adalah (1). mempelajari teknik produksi, pemasaran serta mengidentifikasi permasalahan teknologi produksi mulai dari penanganan dan standarisasi bahan baku produksi madumongso dan teknologi produksinya, manajemen, penanganan produk akhir dan pemasaran madumongso termasuk perlindungan hukum terhadap produk di UKM Kelapa Sari Kabupaten Blitar. (2). Memberikan solusi alternatif terhadap permasalahan yang telah teridentifikasi.

\section{METODE}

Metode pelaksanaan pengabdian pada masyarakat dilakukan dengan survey langsung pada UKM jenang Madumongso Kelapa Sari di Jl. Masjid 46 Desa Rejowinangun Kec. Kademangan Kabupaten Blitar. Untuk melengkapi data juga dilakukan wawancara langsung dengan pemilik UKM. Pelaksanaan survery mulai bulan Maret sampai Agustus 2017.

Survey dan kegiatan pada UKM dibagi dalam beberapa bidang diantaranya :
1) Bidang Penanganan dan standarisasi bahan baku

Pada tahapan ini dipelajari tengan bahan baku yang terdiri dari rasio ketan hitam dengan ketan, meliputi kadar air awal, varietas, umur panen, dan masa simpan maksimal. Penggunaan pasta nanas sebagai pengawet alami madumongso.

2) Bidang Proses produksi.

Pengamatan pada bidang Produksi difokuskan pada 3 hal yaitu :

a) Proses pengendalian pemasakan

Pada kegiatan pengendalian pemasakan dipelajari tentang penggunaan bahan bakar.

\section{b) Pengadukan adonan}

Pada kegiatan ini dipelajari tentang teknik pengadukan yang dilakukan, efisiensi, kecepatan pengedukan, dan control kualitas.

\section{c) Penanganan produk akhir}

Pada kegiatan ini dipelajari tentang cara pengemasan, teknik lebeling, merek dagang, informasi nilai gizi dan informasi kehalalan produk madumongso.

\section{3) Pasar}

Pengamatan terhadap perluasan segmentasi pasar yang telah dilakukan terhadap model promosi yang menggunakan media cetak (koran) dan elektronik (radio dan televisi), media social online.

\section{HASIL DAN PEMBAHASAN}

\subsection{Penanganan Dan Standarisasi Bahan Baku}

Untuk menunjang keberlanjutan kegiatan UKM madumongso Kelapa Sari menggunakan bahan baku utama berupa ketan hitam dan ketan, santan kelapa kanil, gula kelapa, ekstrak buah nanas, dan ragi. Kebutuhan bahan baku utama pada UKM Kelapa Sari setiap hari adalah ketan 20 kg; 100 biji kelapa; 15 kg gula. Jumlah tersebut bisa meningkat dengan tajam pada bulan-bulan tertentu seperti menjelang idul Fitri, Tahun baru dan bulan-bulan dimana orang banyak punya hajad pernikahan. Keterbatasan ketersediaan kelapa yang sudah tua dan nanas menjadi kendala tersendiri bagi UKM Kelapa Sari karena panen bersifat musiman sehingga berpengaruh pada harga. Untuk menghasilkan madumongso yang berkualitas baik maka spesifikasi bahan baku yang diperlukan harus memenuhi standar (Gambar 1).

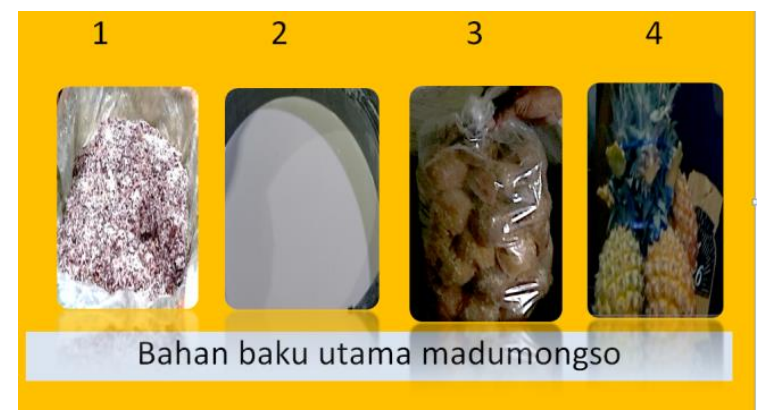

Gambar 1. Bahan baku utama madumongso 
Keterangan :

1) Ketan hitam dan ketan putih yang telah dikukus dan difermentasi

2) Santan Kelapa kanil

3) Gula Kelapa

4) Buah Nanas

Ketan hitam dan ketan putih yang digunakan dengan perbandingan 1 : 3 dikukus sampai matang membutuhkan waktu sekitar 30 menit. Bahan tersebut selanjutnya didinginkan dan difermentasi menggunakan ragi tape, setiap kilogram ketan membutuhkan ragi antara 10 - 20 gram (Abdillah, Widyawati \& Suprihati, 2014). Lama pemeraman antara 2 - 3 hari tergantung pada suhu pemeraman (Gandjar, 2003). Pada proses fermentasi akan menghasilkan ketan yang lebih manis dan siap untuk diproses menjadi bahan utama madumongso.

Bahan santan kelapa dipilih dari kelapa yang sudah tua yang bisa menghasilkan santan kanil. Gula kelapa dipilih berdasarkan warna yang kecoklatan, tidak lembek dan rasa manis, sedangkan ekstrak nanas dipilih dari nanas yang sudah matang yang kaya akan asam-asam organic alami yang mampu bertindak sebagai bahan pengawet alami (Sukamto, 2016). Ragi

Tahap 1. Pembuatan Tape Ketan

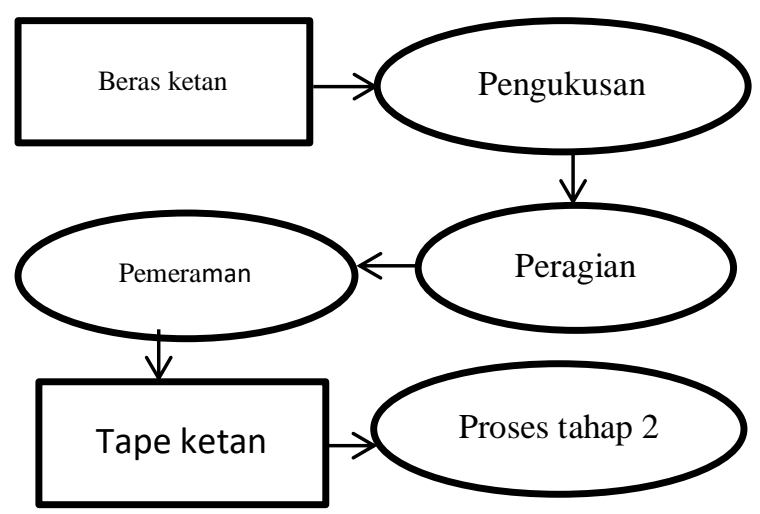

tape diperguankan untuk proses fermentasi campuran ketan hitam dan ketan putih sehingga menghasilkan tape ketan yang mempunyai rasa manis dan aroma yang khas untuk bahan bahan utama madumongso. Proses pembuatan madumongso pada UKM Kelapa Sari tidak menggunakan bahan tambahan kimiawi.

Kontrol kualitas pada bahan baku dilakukan pada ketan putih maupun ketan hitam dimana umur simpan kurang dari 1 bulan, kadar air awal bahan baku tersebut \pm 12 persen. Rasio ketan hitam dengan ketan putih adalah $1: 3$.

\subsection{Teknologi Proses Produksi}

Produksi madumongso di Usaha Kecil Menengah (UKM) Kelapa Sari sangat dipengaruhi oleh permintaan pasar. Rata-rata produksi 0,9 ton sampai 1,5 ton madumongso per bulan. Jika dilihat dari peralatan yang tersedia kapasitas produksinya masih dapat memenuhi permintaan pasar. Rata-rata biaya produksi adalah $\mathrm{Rp} 1.000 .000,--\mathrm{Rp} 1.500 .000$,- per 1 kuintal produk madumongso. Hasil pelaksanaan kegiatan menunjukkan bahwa proses produksi madumongso di UKM Kelapa Sari memiliki 2 tahapan yaitu tahapan pembuatan tape ketan dan tahapan proses pemasakan madumongso (Gambar 2).

Tahap 2. Proses pembuatan Madumongso

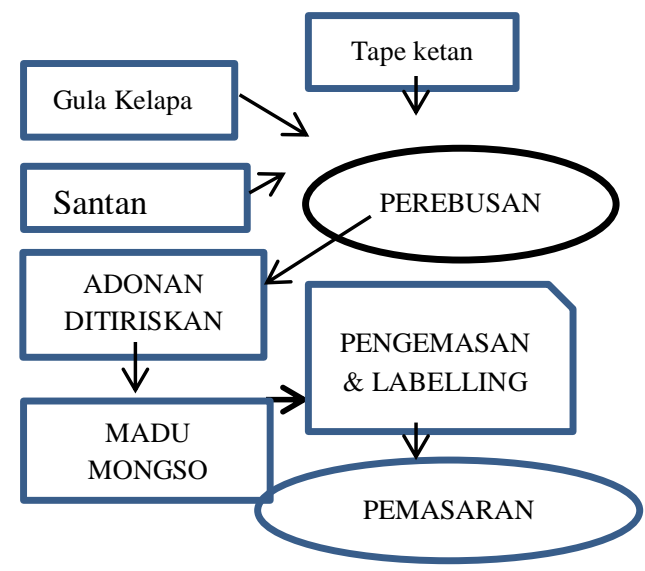

Gambar 2. Proses produksi madumongso di UKM Kelapa sari di Kabupaten Blitar

Pada tahap pertama ketan hitam dan ketan putih dicampur dengan perbandingan $1: 3$ dan direndam dalam air dengan perbandingan antara ketan dengan air adalah $1: 3$. Bahan selanjutnya ditanak selama 30 menit sampai 40 menit dan beras ketan benar-benar matang. Setelah matang beras ketan ditiriskan dan diberi ragi tape sampai merata fermentasi dilakukan pada kondisi anaerob. Proses fermentasi membutuhkan waktu pemeraman 2 -3 hari. Beras ketan yang telah mengalami fermentasi ditandai dengan rasa lebih manis dan bau khas tape (Sukamto et al. 2016). Pada tahap kedua adalah proses pembuatan
madumongso. Tahap awal adalah melakukan perebusan serta pengadukan santan kelapa dan gula kelapa sampai gula terlarut seluruhnya. Selanjutnya bahan ketan hasil fermentasi serta pasta nanas dimasukkan kedalam adonan, bahan diaduk terus menerus sampai legit dan membutuhkan waktu sekitar 3 jam. Setiap proses produksi madumongso memerlukan proporsi bahan tape ketan 20 kilogram, santan kelapa yang telah diperas dari 100 biji kelapa dan ditambah $25 \mathrm{~kg}$ gula kelapa. Proses pemasakan madumongso menggunakan peralatan wajan besar yang terbuat dari tembaga yang disebut Jedi (Gambar 3) sehingga dapat menghasilkan citarasa dan aroma khas madumongso (Sukamto et al. 2016). 


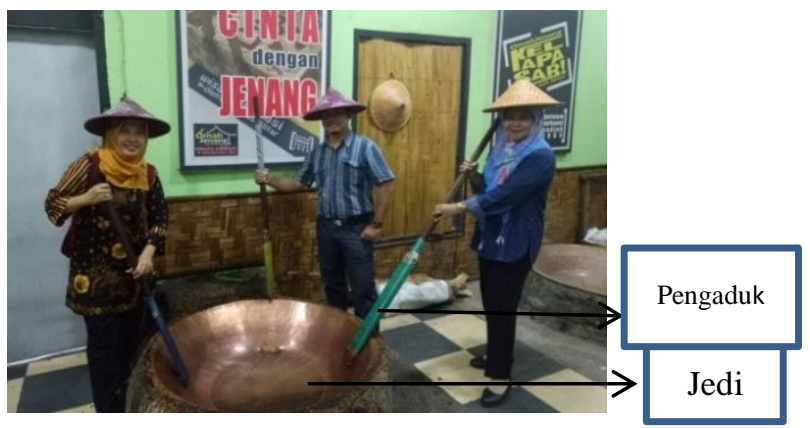

Gambar 3. Jedi tempat untuk pemasakan jenang Madumongso

Proses pemasakan menggunakan wajan tembaga (Jedi) diameter 1 meter yang dirangkai dengan pengaduk semi otomatis yang digerakkan oleh mesin penggerak Disel (Gambar 4). Pemasakan seluruh adonan diaduk dalam wajan tembaga (Jedi) dan dipanaskan menggunakan kayu bakar sampai seluruh adonan kental dan legit. Proses pemasakan dan pengadukan dilakukan oleh mesin pengaduk dan dibantu tenaga manusia dengan menggunakan tongkat entong/sutil. Produk akhir pasca pemasakan dan pengadukan yang sudah kental dan legit sesuai dengan yang didinginkan dan selanjutnya dapat dibentuk seperti batang mirip sosis (Gambar 5). Hasil perbaikan teknologi proses produksi yang menggunakan mesin pengaduk semi otomatis dapat menghasilkan produk akhir yang lebih seragam dan kualitas yang lebih terkontrol (Sukamto et al. 2016). Keunggulan dari peralatan ini adalah waktu dan tenaga yang dibutuhkan dapat dihemat dibandingkan dengan pemasakan dan pengadukan yang menggunakan tenaga manusia penuh. Selama pemasakan dan pengadukan terjadi proses interaksi antara senyawa gula dan protein membentuk rekasi Mailard serta terjadinya reaksi caramel (karamelisasi). Permasalahannya adalah selama proses pengadukan dan selama pemasakan jika tidak ada standar proses yang jelas menyebabkan produk akhir tidak seragam terutama warna akibat adanya reaksi Mailard dan karamelisasi yang tidak terkendali dengan baik (Gambar 5).

Didalam pembuatan madu mongso digunakan kelapa yang tua atau semanten (bahasa jawa) karena menghasilkan banyak santan, dan apabila kelapanya terlalu tua santan yang dihasilkan mengandung banyak minyak sehingga akan mempengaruhi rasa yang dihasilkan dan mengurangi daya simpan pada madu mongso karena mengakibatkan ketengikan (Anindiya, 2015).

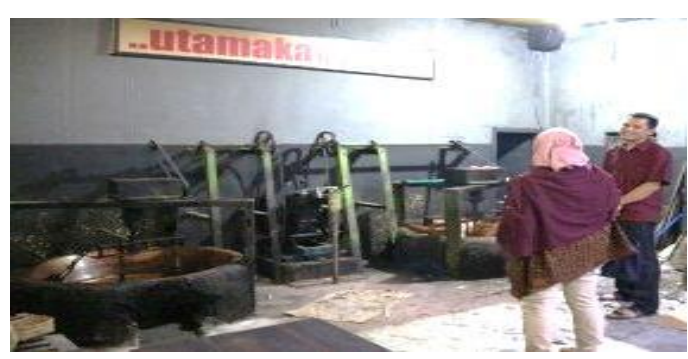

Rancangan alat pemasakan madumongso

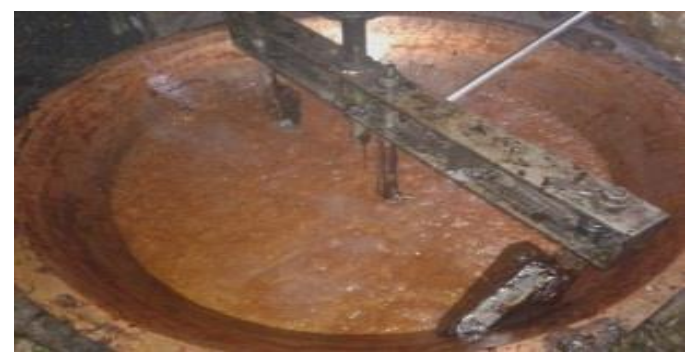

Pelarutan santan kelapa dengan gula

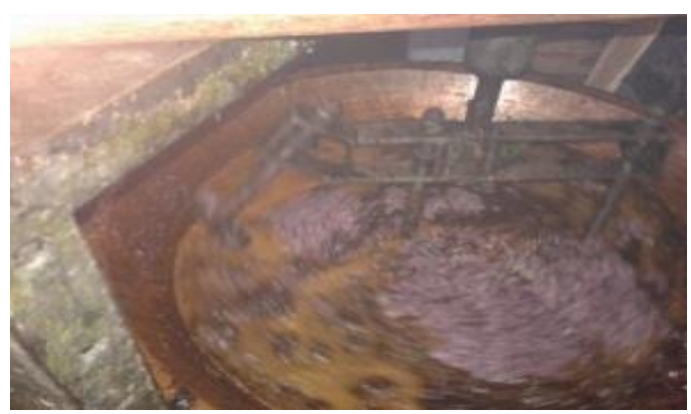

Pemasakan madumongso dari tape ketan dan pasta nanas

Gambar 4. Rancangan proses pemasakan madumongso
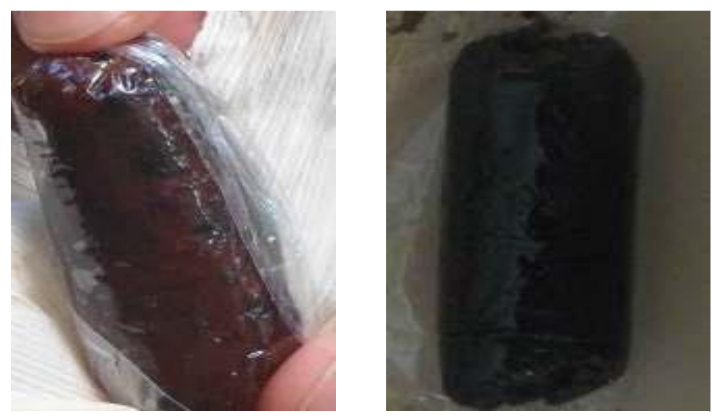

Gambar 5. Produk akhir madumongso pasca pemasakan

\subsection{Penanganan Produk Akhir}

\section{a) Pengemasan Dan Pengepakan}

Pengemasan madumongso menggunakan bahan plastik, kulit tongkol jagung (klobot) dan kertas (Gambar 6a). Satu (1) buah madumongso berukuran panjang $5 \mathrm{~cm}$ diameter $1 \mathrm{~cm}$ dan berbentuk batang (Gambar 6b). Sedangkan bentuk produk kemasan klobot (Gambar 6c). 

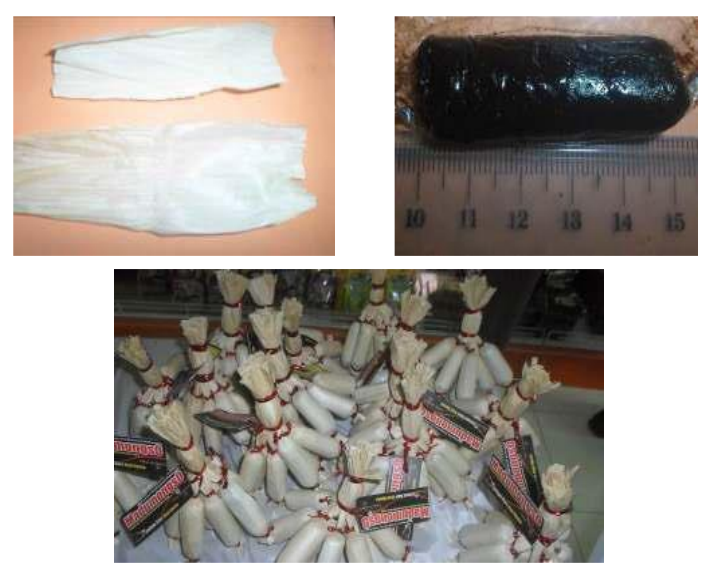

Gambar 6. Bahan kemasan klobot jagung (a), Madumongso (b) dan hasil kemasan madumongso (c)

Kulit (klobot) jagung diperoleh dari Kediri seharga Rp $2000,-/ \mathrm{kg}$ dan sudah menjadi mitra tetap bagi UKM madumongso, sedangkan kemasan plastic dan kertas dibeli dari toko kemasan plastik di Kota Blitar. Pengepakan menggunakan 10 model pak yaitu mika 250, mika 750, klobot $1 \mathrm{~kg}$, keranjang isi 250 biji, besek isi 250 biji, tas, kardus dan anyaman (Gambar 7). Cara pengepakan menggunakan cara manual dan melibatkan tenaga kerja manusia terutama wanita. Kapasitas dari isi produk disesuaikan dengan harga jual. Kreasi kemasan pada UKM cukup unik dan menarik karena sebagaian besar menggunakan bahan alam seperti kulit jagung (klobot) dan anyaman bambu. Biaya untuk pengepakan sangat bervariasi antara Rp2500,- sampai Rp4000,- per pak
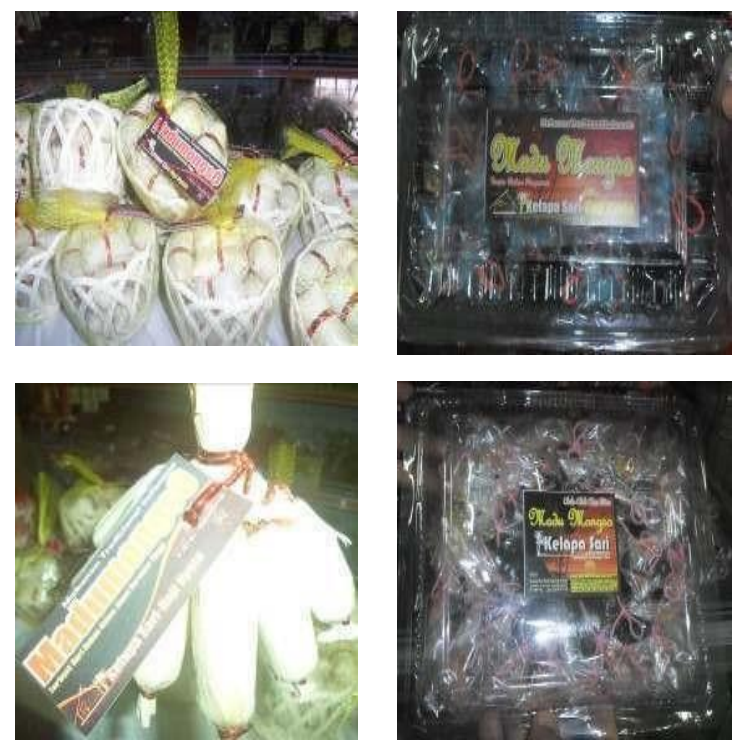

Gambar 7. Beberapa model pengepakan madumongso di UKM Kelapa Sari

adaıan peıum aıtemukan ınıoması mengenaı ınıormasi halal, komposisi bahan dan komposisi gizi/nutrisi. Setelah didalami lebih lanjut ternyata merek kelapa sari belum berhasil didaftarkan ke Dirjen HKI karena ada merek yang lebih dahulu mendaftar yaitu merek sari kelapa. Kondisi tersebut mudah digunakan oleh pihak lain karena tidak mempunyai kekuatan hukum tetap. Kegiatn pengabdian masyarakat pada tahun 2017 telah berhasil mendaftarkan merek dagang dengan nama ODJEPARI (Gambar 8) dan saat ini sedang menunggu granted.

Label halal merupakan bentuk pengakuan bahwa produk madumongso menggunakan bahan-bahan dan proses produksi yang halal yang dikuatkan oleh sertifikat halal yang diberikan oleh LPPOM - MUI Jawa Timur. Konsumen atau masyarakat sangat membutuhkan informasi tersebut untuk memperoleh jaminan bahwa produk yang akan dikonsumsi benarbenar halal, aman dengan nilai gizi yang jelas (Hidayat dan Siradj, 2015).

\subsection{Perkembangan Produksi Dan Pasar}

UKM Kelapa Sari dan "Ciptarasa" telah melakukan usaha sejak tahun 1985, bentuk-bentuk kelompok usaha bersama sebenarnya sudah dirintis. Sistem pemasaran dilakukan dengan bermitra dengan komunitas "SEGORO" yang berpusat dikota Blitar. Komunitas tersebut mengelola tentang pengadaan 1000 parsel dan pembinaan pasar untuk luar negeri. Model pemasaran dilakukan dengan 3 cara yaitu :

a) Konsumen datang langsung pada stan Rumah Jenang Madumongso Kelapa Sari.

Pada lokasi tersebut konsumen/wisatawan dalam melihat langsung proses pembuatan jenang, madumongso, dan wajik klentik. Toko menyediakan berbagai macam produk UKM dari berbagai wilayah Blitar. Model penataan dan display produk dapat dilihat pada Gambar 9.

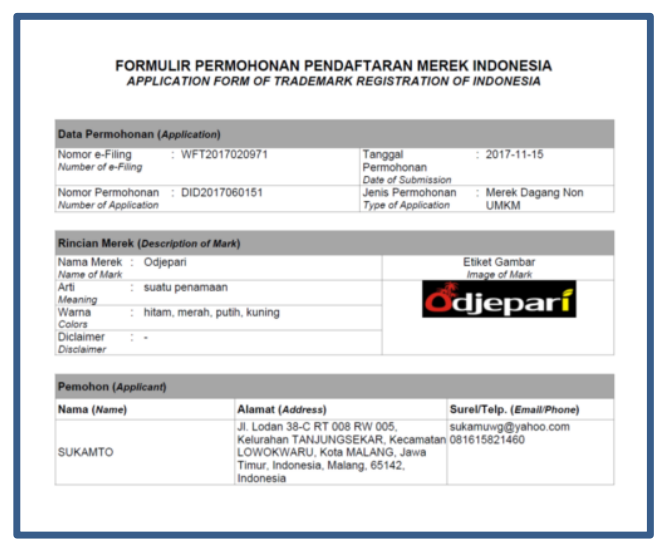

Gambar 8. Desain gambar merek y ang didaftarkan ke Dirjen HKI, Kemenkumhan Republik Indonesia 


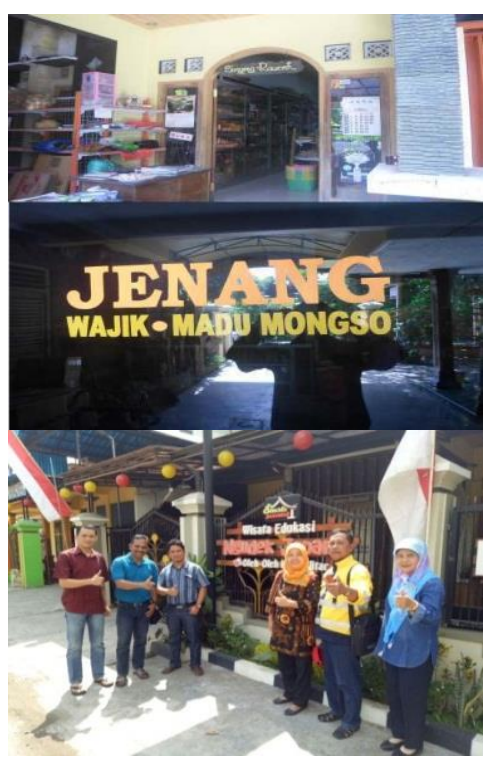

Gambar 9. Model penataan dan display produk UKM Kelapa Sari

\section{b) Kerjasama dengan berbagai Toko}

Untuk memperluas segmentasi pasar, kedua UKM bekerjasama dengan berbagai toko penjual produk UKM di berbagai kota di Jawa Timur dan Jogjakarta seperti Malang, Jember, Tuban, dan hampir seluruh kota di Jawa Timur kecuali Kabupaten Pacitan. Sedangkan yang antar pulau produk madumongso sudah dipasarkan di Pulau Kalimantan, Bali, Sumatera, Batam dan Sulawesi. Kusus untuk pasar luar pulau terkendala pada distribusi/pengiriman, sehingga model penjualan dilakukan pada saat pengusaha dari luar pulau tersebut datang ke Blitar sambil kulakan untuk dibawa pulang dan dijual.

\section{c) Pasar Luar Negeri}

Pemasaran luar negeri sementara ini dilakukan oleh Tenaga kerja Indonesia (TKI) yang

bekerja di Hongkong yang mampu memasarkan produk madumongso 1 kuintal per tahun. Disamping itu produk madumongso juga dibawa oleh TKI pada saat pulang ke Blitar dan dijual di Negara tujuan seperti Arab Saudi, Taiwan, Malaysia, dan Singapura (Sukamto, 2016). Jika dijumlahkan produk madumongso yang terjual di Luar Negeri hampir 1 ton per tahun. Pasar dalam negeri maupun luar negeri potensinya masih sangat besar namun karena kapasitas produksi dan tenaga pemasaran yang masih terbatas. Pengenalan produk melalui iklan di media cetak, elektronik dan media social internet sudah malai dirintis dan diharapkan dapat mempercepat perluasan segmentasi pasar.

Data produksi Madumongso bulan Maret sampai bulan Juli tahun 2017 dibandingkan dengan tahun 2016 pada setiap bulan dapat dilihat pada Tabel 1. Sedangkan perkembangan pendapatan kotor pada UKM Kelapa Sari berfluktuasi. Pada bulan-bulan menjelang hari raya dan setelah hari raya idul Fitri terlihat pasar mengalami peningkatan sehingga pendapatan kotor juga mengalami peningkatan yang cukup signifikan sejalan dengan perkembangan produksi (Tabel 2). Produksi dan permintaan madumongso pada bulan-bulan Mei sampai Juli pada setiap tahun mengalami peningkatan yang cukup besar (Sukamto et al. 2016). Disamping itu permintaan jenang madumongso juiga didukung olah Lokasi yang berdekatan dengan lokasi wisata Kampung Coklat dan wisata Makam Proklamator Bung Karno. Kondisi tersebut memberikan dampak positif terhadap wisata jenang madungmongso. Peran Pemerintah Daerah Kabupaten Blitar sangat besar dalam mendukung kegiatan wisata kuliner termasuk pada UKM Jenang Madumongso Kelapa sari.

Tabel 1. Perkembangan Produksi Madumongso UKM Kelapa Sari tahun 2016 dan tahun 2017, bulan Maret sampai Juli

\begin{tabular}{cccc}
\hline \multirow{2}{*}{ No } & \multirow{2}{*}{ Bulan } & \multicolumn{2}{c}{ Produksi $(\mathbf{k g})$} \\
\cline { 3 - 4 } & & $\mathbf{2 0 1 6}$ & $\begin{array}{c}\text { Tahun } \\
\mathbf{2 0 1 7}\end{array}$ \\
\hline 1 & Maret & 900 & 950 \\
2 & April & 950 & 1000 \\
3 & Mei & 1200 & 1300 \\
4 & Juni & 1400 & 1500 \\
5 & Juli & 1400 & 1600 \\
\hline
\end{tabular}

Tabel 2. Pendapatan kotor pada UKM Kelapa Sari tahun 2016 dan 2017 pada Maret sampai Juli

\begin{tabular}{cccc}
\hline & & \multicolumn{2}{c}{ Pendapatan kotor (Rp) } \\
\cline { 3 - 4 } No & Bulan & Tahun 2016 & Tahun 2017 \\
\hline 1 & Maret & $64.021 .000,-$ & $25.961 .000,-$ \\
2 & April & $33.826 .000,-$ & $11.599 .500,-$ \\
3 & Mei & $48.988 .000,-$ & $70.681 .000,-$ \\
4 & Juni & $93.507 .000,-$ & $57.837 .000,-$ \\
5 & Juli & $37.564 .000,-$ & $75.530 .000,-$ \\
\hline
\end{tabular}

\section{KESIMPULAN DAN SARAN \\ 4.1 Kesimpulan}

Profile UKM jenang Madumongso Kelapa Sari di Kabupaten Blitar berjalan cukup baik dilihat dari beberapa aspek teknologi produksi dan manajemen setelah melalui berbagai pembinaan dan pendampingan. Aspek labeling, perlindungan hukum terhadap proses, labelisasi halal dan merk dagang telah diupayakan melalui kegiatan pengabdian masyarakat skema IbPE 2016 dan 2017 dan sekarang sedang menunggu granted.

Potensi pasar dalam dan luar negeri mengalami terus mengalami peningkatan $10 \%$ sampai $20 \%$ setiap tahunnya karena didukung oleh lokasi UKM yang berdekatan dan berinteraksi dengan wisata lainnya seperti Kampung Coklat, Makam Bung Karno yang berada di wilayah Kabupaten dan Kota Blitar.

\subsection{Saran}

Perluasan pasar perlu dikembangkan baik melalui cara konvensional maupun melalui sosial media. Implementasi informasi kehalalan produk, merek 
dagang, informasi bahan dan nilai gizi produk madumongso dalam label kemasan perlu segera ditindaklanjuti.

\section{UCAPAN TERIMA KASIH}

Terima kasih kepada Direktorat Riset dan Pengabdian kepada Masyarakat (DRPM) Kementerian Riset dan Teknologi Dikti yang telah memberikan dana dalam pelaksanaan kegiatan melalui program Pengabdian Masyarakat Skema IbPE anggaran tahun 2016-2018.

\section{DAFTAR PUSTAKA}

Abdillah, J., Widyawati, N. \& Suprihati (2014). Pengaruh Dosis Ragi dan Penambahan Gula terhadap Kualias Gizi dan Organoleptik Tape Biji Gandum. Agric 26(2) : $75-84$.

Anindya, A.T.U. (2015). Pengaruh Penggunaan Tape Pisang yang Berbeda terhadap Kualitas Inderawi Madumongso. Thesis, Universitas Negeri Semarang.

GANDJAR, I. (2003). Tapai from cassava and cereals. Dalam: First International Symposium and Workshop on Insight into the World of Indigenous Fermented Foods for Technology Development and Food Safety (pp-1-10). Bangkok.

Hidayat, A.S. \& Siradj. M. (2015). Sertifikasi Halal dan Sertifikasi Non Halal pada Produk Pangan Industri. Ahkam 15(2) : $199-210$.

http://,wikipedia.org /wiki/madu_mongso. Diakses Agustus 2017.

Nailufar. A.A., Basito \& Anam, C. (2012). Kajian Karakteristik Ketan Hitam (Oryza sativa glutinosa) pada Beberapa Jenis Pengemasan Selama Penyimpanan. J. Teknosains Pangan 1(1), 121-133.

Sukamto. 2016. Madumongso "Go International" Berkat Jasa TKI. Kompasiana. http://www.kompasiana.com/tokam/madumong so- go-international-berkat-jasa-tki_

Sukamto, Sudiyono, Wulandari, W. \& Figih, H.P. (2016). Prospek Produk Pangan Tradisional Madumongso dalam Memasuki Pasar Ekspor. Dalam Seminar Nasional Hasil Penelitian dan Pengabdian Kepada Masyarakat (pp-229-233). Malang, Indonesia : Universitas Kanjuruhan. 